\title{
KEBIJAKAN MEDIASI PENAL DALAM PENYELESAIAN PERKARA TINDAK PIDANA RINGAN PERSPEKTIF RESTORATIVE JUSTICE
}

\author{
Oleh: Lysa Angrayni \\ Dosen Fakultas Syariah dan Hukum UIN Sultan Syarif Kasim Riau \\ Alamat Kantor JI. HR. Soebrantas KM 15 Simpang Baru Panam Pekanbaru \\ Email: Lysa.Angrayni@gmail.com
}

\begin{abstract}
Abstrak
Kejahatan yang tergolong ringan dengan kerugian relatif kecil lebih tepat diselesaikan melalui sarana mediasi penal. Namun, legalitas dari mediasi penal belum diakomodir dalam sistem hukum pidana di Indonesia. Berdasarkan fenomena tersebut penulis tertarik membahas penyelesaian perkara tindak pidana ringan dalam sistem peradilan pidana, dengan permasalahan: Apa dasar/alasan untuk menentukan kebijakan dalam menggunakan sarana mediasi penal dalam penyelesaian perkara tindak pidana ringan? Apa urgensi mediasi penal dalam penyelesaian perkara tindak pidana ringan sebagai upaya perwujudan restorative justice? Metode penelitian menggunakan penelitian hukum normatif dapat disebut sebagai penelitian hukum doktrinal. Hasil penelitian ini menyimpulkan dasar/alasan untuk menentukan kebijakan dalam menggunakan sarana mediasi penal dalam penyelesaian perkara tindak pidana ringan: Pertama, perlu memberikan rumusan yang tegas berkenaan dengan ketentuan mediasi penal. Kedua, dalam menentukan kebijakan untuk memformulasi mediasi penal dalam sistem peradilan pidana di Indonesia, perlu ditentukan kriteria tindak pidana yang dapat diselesaikan melalui jalur mediasi penal. Urgensi mediasi penal dalam penyelesaian perkara tindak pidana ringan perspektif restorative justice dari aspek administrasi peradilan adalah untuk mengurangi penumpukan perkara. Peningkatan jumlah perkara yang masuk ke pengadilan untuk saat ini menyebabkan semakin banyaknya beban pengadilan untuk menyelesaikan perkara dengan waktu yang terbatas. Namun, dapat dikemukakan urgensi perlunya mediasi penal dalam penyelesaian perkara tindak pidana ringan apabila dilihat dari perspektif restorative justice, sebagai berikut: Pertama, karena masyarakat yang lebih mendominasi berkembangnya sistem hukum. Kedua, perlunya menghadirkan hukum modern menggantikan hukum tradisional.
\end{abstract}

\begin{abstract}
Crime relatively light with relatively small losses more appropriately resolved by means of penal mediation. However, the legality of penal mediation has not been accommodated in the criminal justice system in Indonesia. Based on this phenomenon the authors interested in discussing the settlement of minor criminal offenses in the criminal justice system, with the problem: What is the basis / rationale for policy decisions in using the means of penal mediation in the settlement of minor criminal offenses? What urgency penal mediation in the settlement of minor criminal offenses in an attempt embodiment of restorative justice? The research method using normative legal research can be referred to as a doctrinal legal research. The results of this study concludes the basis I rationale for policy decisions in using the means of penal mediation in the settlement of minor criminal offenses: First, it should provide a clear formulation with regard to the provisions of penal mediation. Second, in determining the penal mediation to formulate policy in the criminal justice system in Indonesia, is necessary to determine the criteria
\end{abstract}


of offenses can be resolved through penal mediation. Urgency penal mediation in the settlement of minor criminal offenses restorative justice perspective on aspects of the administration of justice is to reduce the accumulation of cases. An increasing number of cases that go to trial to date to cause more burden the court to settle the case with a limited time. However, it can be argued the urgency of the need for penal mediation in the settlement of minor criminal offenses, when viewed from the perspective of restorative justice, as follows: First, because the people who dominate the development of the legal system. Second, the need to present a modern law replaces the traditional law.

\section{Kata kunci: Mediasi Penal, Tindak Pidana Ringan, Restorative Justice}

\section{Pendahuluan}

Sistem hukum pidana di Indonesia mengisyaratkan bahwa pelaksanaan pidana pada hakikatnya terlepas dari kemauan seseorang. Ketentuan hukum pidana tetap terlanggar, meskipun ada persetujuan dari pihak yang dirugikan. Tentu saja hal tersebut berbeda dengan sistem dalam hukum perdata. Ilmu pengetahuan hukum mengenal ada pemisahan antara hukum publik dan hukum privat. Namun, dalam hubungan tertentu, ada yang mengandung unsur publik dan privat sekaligus. Pada pokoknya, hukum mengatur tingkah laku manusia di dalam kehidupan bermasyarakat maka kepentingan masyarakat selalu menjadi faktor dibuatnya hukum. Namun, dalam hubungan tertentu hukum mentitikberatkan pada kepentingan satu orang manusia, sedangkan pada hubungan lainnya menitik-beratkan pada kepentingan umum. ${ }^{1}$

Hukum publik, dalam hal ini pidana sangat berbeda dengan perdata. Dalam pidana, segala masalah yang timbul akan diserahkan kepada Negara untuk menyelesaikannya. Meskipun dalam teori hukum acara pidana, penyerahan penyelesaian kepada Negara tersebut berbeda-beda. Ada yang harus dilapor, ada pula yang harus diadukan. ${ }^{2}$ Salah satu fenomena yang perlu dicermati, yaitu upaya damai yang dilakukan ketika timbul dugaan tindak pidana.

Upaya damai yang dilakukan di luar pengadilan ketika timbul dugaan tindak pidana, seperti halnya dalam perkara perdata, hanyalah merupakan penyelesaian di bawah tangan. Upaya damai yang dilakukan di luar pengadilan dapat contohkan seperti perdamaian antara korban dengan pelaku tindak pidana pencurian (kejahatan).

Untuk perkara perdata, upaya damai merupakan hal yang sudah terlegitimasi dengan asas dan peraturan yang terkait dengan keperdataan. Namun, untuk perkara pidana, upaya perdamaian merupakan suatu hal yang patut dipertanyakan. Pertanyaan itu, timbul karena suatu ketentuan bahwa "tak ada perdamaian dalam pidana" dan "tercapainya perdamaian, tidak menghilangkan unsur pidana yang ada". Banyak perkara pidana kecil dapat diproses dengan asas peradilan yang cepat, biaya ringan, dan sederhana. Misalnya, orang yang mencuri pisang karena lapar, sedangkan pemilik pisang dapat memaafkan maka konsekuensi etisnya tidak perlu diputus di

${ }^{1}$ Wirjono Prodjodikoro, Asas-asas Hukum Pidana di Indonesia, (Jakarta: Refika Aditama, 2003), hlm. 2.

${ }^{2}$ S.R. Sianturi dan Mompang Panggabean, Hukum Penitensia di Indonesia, (Bandung: Alumni, 1996), hlm. 81. 
pengadilan, tetapi diselesaikan melalui mediasi penal.

Menanggapi fenomena tersebut menurut Suteki, seringkali sebagian masyarakat memahami hukum hanya sekedar sebagai perangkat peraturan hukum positif yang tercerabut dari aspek pemahaman filosofi dan sosiologisnya. Pemahaman demikian, menggambarkan hukum tidak utuh, melainkan hanya sebuah fragmen atau skeleton, yakni peraturan perundang-undangan saja. Hal tersebut mendorong munculnya anggapan bahwa apabila hukum telah diselenggarakan sebagaimana tertulis yang berupa huruf-huruf mati (black letter law) seolah-olah pekerjaan pencarian keadilan itu telah selesai. Akibatnya, muncul banyak kasus yang mencerminkan kondisi bahwa keadilan substansial telah teralienasi dari hukum. Hukum tidak membumi, bahkan mencederai rasa keadilan dalam masyarakat. Penanganan secara hukum atas tindak pidana di Indonesia seperti halnya kekuatan jaring laba-laba. la hanya mampu menjerat kejahatan-kejahatan kecil, namun tidak sanggup menyentuh kejahatan yang berukuran besar. la mencontohkan beberapa fenomena peradilan terhadap rakyat kecil (the poor), seperti: $^{3}$

"1. Kasus pencurian satu buah semangka (di Kediri), Cholil dan Basyar Suyanto dipidana 15 hari percobaan 1 bulan.

2. Kasus pencurian kapuk randu seharga Rp 12.000,00 (4 anggota keluarga ditahan di LP Rowobelang) dan para terdakwa dipidana penjara 24 hari.
3. Kasus Pak Klijo Sumarto (76) tersangka pencurian setandan pisang Kluthuk mentah seharga Rp 2.000,00 di Sleman, 7 Desember 2009 (mendekam di LP Cebongan Sleman).

4. Kasus Mbok Minah (dituduh mencuri 3 biji kakao seharga Rp 2.100,00, 2 Agustus 2009, dihukum pidana percobaan 1 bulan 15 hari).

5. Kasus pencurian sepasang sendal jepit anggota Polisi yang dilakukan oleh AAL (15 tahun) yang tetap dinyatakan bersalah meskipun sendal yang dimaksud terbukti bukan milik anggota Polisi yang bersangkutan".

Fenomena tersebut memperlihatkan bahwa mahalnya keadilan bagi masyarakat kecil dan rumitnya keadilan bagi kejahatan ringan dengan kerugian yang tidak besar. Namun, penyelesaian perkara pidana mesti melalui suatu prosedur mulai dari penyelidikan sampai dengan diputuskan oleh pengadilan. Penyele-saian tersebut jelas membutuhkan tenaga, waktu dan pemikiran yang tidak sedikit sehingga dianggap tidak seimbang dengan efek perbuatan yang dilakukan. Keadaan tersebut menimbulkan pertanyaan mengapa untuk perkara kecil tidak diselesaikan melalui jalur mediasi saja? Padahal mediasi penal merupakan alternatif penyelesaian tindak pidana di samping pengadilan, lebih cepat, murah, dan memberikan akses kepada para pihak yang bersengketa memperoleh keadilan atau penyelesaian yang memuaskan. ${ }^{4}$

${ }^{3}$ Suteki, Kebijakan Tidak Menegakkan Hukum (Non Enforcement Of Law) Demi Pemuliaan Keadilan Substansial, Pidato Pengukuhan, Disampaikan pada Penerimaan Jabatan Guru Besar Dalam Ilmu Hukum Pada Fakultas Hukum Universitas Diponegoro Semarang pada 4 Agustus 2010, hlm. 5-7 sebagaimana dikutip oleh Muhammad Taufiq, Keadilan Substansial Memangkas Rantai Birokrasi Hukum, (Yogyakarta: Pustaka Pelajar, 2014), hlm. 4-5.

${ }^{4}$ Supriyadi, Mediasi Penal Sebagai Alternatif Penyelesaian Perkara Penggelapan Benda Jaminan Fidusia, Jurnal MMH, Jilid 43, Nomor 3, Juli 2014, hlm. 424. 
Tetapi, persoalan yang dihadapi penegakan hukum pidana di Indonesia adalah belum adanya wadah hukum penyelesaian perkara pidana melalui mediasi. Doktrin hukum yang masih berlaku adalah perkara pidana tak bisa dimediasi. Proses peradilan pidana merupakan laboratorium akal sehat karena menguji kebenaran fakta hukum dengan kacamata hukum dan hati nurani untuk menghasilkan kebenaran dan keadilan bagi pelaku dan korban. Dengan pemikiran tersebut perlu adanya pemikiran untuk menyelesaikan perkara pidana melalui jalur mediasi penal sebagai upaya untuk menyelesaikan konflik yang terjadi secara menyeluruh sehingga para pihak yang berperkara dapat menyelesaikan masalah dengan kesadaran sendiri dan mengutamakan saling pengertian dan penghormatan kepada hak-hak korban. Namun, kebijakan tersebut harus diimbangi dengan ketentuan yang menyangkut metode mediasi penal yang dilegitimasi oleh aturan hukum yang menentukan batasan penggunaan sarana mediasi penal, terutama terhadap perkara yang digolongkan kepada tindak pidana ringan yang dari aspek akibat ditimbulkan tidak terlalu berbahaya.

Kebijakan tersebut diperlukan agar proses perdamaian "di bawah tangan" yang terjadi di masyarakat, seperti yang terjadi di Kepolisian sebagai tahap awal proses peradilan pidana dapat dilegitimasi oleh aturan yang memberikan kepastian hukum, keadilan dan kemanfaatan. Oleh karena itu, berdasarkan fenomena tersebut maka penulis tertarik membahas penyelesaian perkara tindak pidana ringan dalam sistem peradilan pidana, dengan permasalahan: Apa dasar/alasan untuk menentukan kebijakan dalam menggunakan sarana mediasi penal dalam penyelesaian perkara tindak pidana ringan? Apa urgensi mediasi penal dalam penyelesaian perkara tindak pidana ringan sebagai upaya perwujudan restorative justice?

\section{Metode Penelitian}

Penelitian terhadap permasalahan di atas dilakukan dengan tipe penelitian hukum normatif. Penelitian hukum normatif bermula dari kajian hukum positif tertulis. Kajian hukum positif tertulis ini dapat disebut sebagai penelitian hukum doktrinal, ${ }^{5}$ yaitu penelitian yang berupa usaha penemuan hukum in concreto yang layak diterapkan untuk menyelesaikan suatu perkara hukum tertentu. Pendekatan terhadap permasalahan dalam penelitian ini menggunakan pendekatan perundang-undangan (statute approach). Selain itu, penelitian ini juga menggunakan pendekatan konseptual dengan mengananalisis teori-teori yang berkaitan dengan mediasi penal dan restorative justice, serta menggunakan pendekatan persepsional dengan menganalisis persepsi penegak hukum yang berkaitan dengan penelitian. Dalam penelitian ini juga melihat bagaimana hukum berperilaku secara in concreto (hukum dalam kenyataan) mengenai hal-hal yang berkaitan dengan masalah penyelesaian perkara tindak pidana ringan sesuai dengan permasalahan yang diteliti.

\section{Tinjauan Pustaka}

Mengenai mediasi penal (penal mediation), peristilahan dan pengertiannya masih sangat sedikit karena wacana tentang mediasi penal baru diperkenalkan di Indonesia. Barda Nawawi Arief sering juga disebut hlm. 45.

${ }^{5}$ Suratman dan Philips Dillah, Metode Penelitian Hukum, Cetakan Ke-2, (Bandung: Alfabeta, 2014), 
dengan berbagai istilah, antara lain: "mediation in criminal cases" atau "mediation in penal matters" yang dalam istilah Belanda disebut strafbemiddeling, dalam istilah Jerman disebut "Der Außergerichtliche Tatausgleich" (disingkat ATA) dan dalam istilah Perancis disebut "de mediation pénale".

Latar belakang pemikirannya ada yang dikaitkan dengan ide pembaharuan hukum (legal reform) dan ada yang dikaitkan dengan masalah pragmatism. Latar belakang ide penal reform itu antara lain ide perlindungan korban, ide harmonisasi, ide restrotative justice, ide mengatasi kekakuan atau formalitas dalam sistem yang berlaku, ide menghindari efek negatif dari sistem peradilan pidana dan sistem pemidanaan yang ada saat ini, khususnya dalam mencari alternatif lain dari pidana penjara (alternative to imprisonment/ alternative to custody). Latar belakang pragmatis antara lain untuk mengurangi penumpukan perkara (the problem of court case overload), untuk penyederhanaan proses peradilan dan sebagainya. $^{6}$

Perlu disadari bahwa secara historis, kultur masyarakat Indonesia sangat menjunjung tinggi pendekatan konsensus. ${ }^{7}$ Pengembangan penyelesaian sengketa di Indonesia sesuai dengan mekanisme pengambilan keputusan secara tradisional dan penyelesaian sengketa secara adat. Alasan kultural bagi eksistensi dan pengembangan $A D R$ di Indonesia tampaknya lebih kuat dibandingkan dengan alasan ketidak efisienan proses dalam menangani sengketa.

Dalam sistem peradilan pidana untuk mengupayakan adanya mediasi penal, dilatar belakangi pemikiran yang dikaitkan dengan ide- ide pembaharuan hukum pidana (penal reform), dan dikaitkan dengan masalah pragmatisme. Latar belakang ide-ide "penal reform" itu antara lain ide perlindungan korban, ide harmonisasi, ide restorative justice, ide mengatasi kekakuan/ formalitas dalam sistem yang berlaku, ide menghindari efek negatif dari sistem peradilan pidana dan sistem pemidanaan yang ada saat ini, khususnya dalam mencari alternatif lain dari pidana penjara (alternative to imprisonment/ alter-native to custody). Latar belakang pragmatisme antara lain untuk mengurangi stagnasi atau penumpukan perkara ("the problems of court case overload"), untuk penyederhanaan proses peradilan.

Mediasi penal dapat dikaji dari perspektif filosofis, sosiologis dan yuridis. Pada perspektif filosofis, eksistensi mediasi penal mengandung asas diterapkannya solusi "menang-menang" (win-win) dan bukan berakhir dengan situasi "kalah-kalah" (lost-lost) atau "menang kalah" (win-lost) sebagaimana ingin dicapai peradilan dengan pencapaian keadilan formal melalui proses hukum litigatif (law enforcement process). Melalui proses mediasi penal maka diperoleh puncak keadilan tertinggi karena terjadinya kesepakatan para pihak yang terlibat dalam perkara pidana tersebut, yaitu antara pihak pelaku dan korban. Pihak korban maupun pelaku diharapkan dapat mencari dan mencapai solusi serta alternatif terbaik untuk menyelesaikan perkara tersebut. Implikasi dari pencapaian ini maka pihak pelaku dan korban dapat mengajukan kompensasi yang ditawarkan, disepakati dan dirundingkan antara mereka bersama sehingga solusi yang dicapai bersifat "menang-menang" (win-win).

${ }^{6}$ Barda Nawawi Arief, Mediasi Penal: Penyelesaian Perkara di Luar Pengadilan, (Semarang: Penerbit Pustaka Magister, 2008), hlm. 21.

${ }^{7}$ Mushadi, Mediasi dan Resolusi Konflik di Indonesia, (Semarang: Walisongo Mediation Center, 2007). hlm. 38. 
Selain itu, melalui mediasi penal ini akan mempunyai implikasi bersifat positif, secara filosofis dicapainya peradilan dilakukan secara cepat, sederhana dan biaya ringan karena pihak yang terlibat relatif lebih sedikit dibandingkan melalui proses peradilan dengan komponen sistem peradilan pidana. Mediasi penal dapat dikaji dari perspektif sosiologis, sesuai dengan kearifan lokal masyarakat Indonesia. Dari perspektif yuridis, persoalan esensialnya mengarah pada pilihan pola penyelesaian sengketa pidana, terkait dengan domain superioritas negara dengan superioritas masyarakat kearifan hukum. Selain dimensi di atas, implikasi lain adalah eksistensi mediasi penal dapat dikatakan antara "ada' dan "tiada". Dikatakan demikian karena karena dalam ketentuan undangundang tidak dikenal dalam sistem peradilan pidana. Akan tetapi, dalam tataran di bawah undang-undang dikenal secara terbatas melalui diskresi penegak hukum dan sifatnya parsial. Padahal, praktik mediasi penal telah dilakukan oleh masyarakat Indonesia dan penyelesaian tersebut dilakukan di luar pengadilan seperti mekanisme lembaga adat.

Menurut Ulpianus ( \pm 200 AD). "justitia est constans et perpetua voluntas ius suum cuique tribuendi". Keadilan adalah kehendak yang ajeg dan menetap untuk memberikan kepada masing-masing bagiannya. Dalam bahasa Inggris terjemahannya berbunyi "to give everbody his own", atau memberikan kepada setiap orang yang menjadi haknya. Inti dari pengertian tersebut bahwa memberikan masing-masing haknya dan tidak lebih, tetapi tidak kurang dari pada haknya. Keadilan tidak hanya dapat diharapkan saja atau dianjurkan saja. Keadilan mengikat setiap orang, sehingga orang mempunyai kewajiban. ${ }^{8}$

Menurut Tony F.Marshall, restorative justice adalah suatu proses semua pihak yang berhubungan dengan tindak pidana tertentu bersama-sama memecahkan masalah dan bagaimana menangani akibat di masa yang akan datang atau implikasinya di masa depan. ${ }^{9}$

Penyelesaian perkara pidana dengan menggunakan pendekatan represif sebagaimana dilaksanakan dalam sistem peradilan pidana di Indonesia pada prinsipnya telah melahirkan keadilan retributif (retributive justice), yang berorientasi pada pembalasan berupa pemidanaan dan pemenjaraan. Dalam perkembangannya timbul wacana orientasi pemidanaan yang mendudukkan korban sebagai bagian yang penting dalam mencapai tujuan pemidanaan. Untuk mencapai tujuan tersebut maka ditawarkanlah suatu sistem penyelesaian perkara pidana yang berorientasi menguntungkan segala pihak, yaitu melalui konsep restorative justice.

Secara harfiah, restorative justice dapat diartikan sebagai pemulihan keadilan bagi korban dan pelaku tindak pidana. Pengertian ini berkembang setelah dimasukkan dalam sistem peradilan pidana, sehingga pengertiannya menjadi proses penyelesaian yang sistematis atas tindak pidana yang menekankan pada pemulihan atas kerugian korban dan atau masyarakat sebagai akibat perbuatan pelaku. Dalam proses penyelesaian ini melibatkan korban dan pelaku secara langsung dan aktif.

${ }^{8}$ Arif Nugroho dan Dyah Hapsari Prananingrum, Ketidakadilan dalam Perjanjian Jual Beli Sayur, Jurnal IImu Hukum, Volume 10, Nomor 2, September 2007, hlm. 212.

${ }^{9}$ Apong Herlina, Restorative Justice, Jurnal Kriminologi Indonesia, Volume 3, Nomor III, September 2004, hlm. 19. 
Menurut Adam Graycar, Directur of Australian Institute of Criminologi, menyatakan bahwa "dalam praktiknya restorative justice, memerlukan dukungan teori reintegrative shaming dalam menyelesaikan konflik". Graycar menjelaskan dengan mensitir pendapat Braithwaite mengenai teori reintegrative shaming, bahwa ada dua segi utama yang melekat pada proses restorative. "Pertama untuk mencapai keberhasilan reintegrasi itu maka proses yang dilakukan harus melibatkan kehadiran dan peran serta masyarakat bagi dukungan terhadap pelaku dan korban. Kedua adalah proses yang memerlukan adanya perasaan malu (shaming) sebagai pencelaan (confrontation) atas perbuatan salah antara pelaku dan korban. Proses melalui pendekatan restorative ini bertujuan: a) menjelaskan kepada pelaku bahwa perbuatan tersebut merupakan perbuatan yang tercela di masyarakat, b) dukungan dan menghargai seseorang walaupun perbuatannya tersebut merupakan perbuatan yang tercela". ${ }^{10}$ Dengan demikian, tujuan dari program restorative tersebut ialah mengembalikan pelaku dan korban ke dalam masyarakat, agar mereka dapat menjadi anggota masyarakat yang bertanggung jawab, mematuhi hukum dan menjunjung tinggi nilainilai yang hidup dalam masyarakat.

Proses peradilan pidana yang bersifat restorative justice berpandangan bahwa mewujudkan keadilan bukan hanya urusan pemerintah dan pelaku kejahatan, tetapi lebih dari itu harus memberikan keadilan secara totalitas yang tidak bisa mengabaikan kepentingan dan hak-hak korban dan masyarakat. Jadi inti restorative justice lebih menekankan pada upaya pemulihan dan bukan pada penghukuman. Sistem pemidanaan yang berlaku sekarang kurang sekali memperhatikan kepentingan korban.

Konsep teori restorative justice menawarkan jawaban atas isu-isu penting dalam penyelesaian perkara pidana, yaitu: Pertama, kritik terhadap sistem peradilan pidana yang tidak memberikan kesempatan khususnya bagi korban (criminal justice system that disempowers individu). Kedua, menghilangkan konflik khususnya antara pelaku dengan korban dan masyarakat (taking away the conflict from them). Ketiga, fakta bahwa perasaan ketidakberdayaan yang dialami sebagai akibat dari tindak pidana harus diatasi untuk mencapai perbaikan (in order to achieve reparation). ${ }^{11}$

Dari rumusan pengertian tersebut dapat diketahui bahwa tujuan restorative justice adalah untuk mewujudkan pemulihan kondisi korban kejahatan, pelaku dan masyarakat berkepentingan (stakeholder) melalui proses penyelesaian perkara yang tidak hanya berfokus pada mengadili dan menghukum pelaku. Tujuan restorative justice adalah memperbaiki kerusakan, memulihkan kualitas hubungan, dan memfasilitasi reintegrasi para pihak yang terlibat dan terkait. Praktik retorative justice menekankan kepada para pelaku dan korban, sehingga penyelesaiannya tidak sekedar berhenti pada penghukuman pelaku, tetapi pencapaian kedewasaan para pihak terkait untuk memperkuat kualitas hubungan untuk kurun waktu yang lebih panjang. ${ }^{12}$

${ }^{10}$ Adam Gaycar, Dalam Australian Institute of Crimonology, trends and Issues in crime and criminal justice, Bullying and Victimisation In School: A Restorative Justice Approach, No. 219, Februari 2002, hlm. 23. http://www.aic.gov.au.

${ }^{11}$ Lihat berbagai definisi lainnya dalam Ivo Aertsen, et.al, "Restorative Justice and the Active Victim: Exploring the Concept of Empowerment", Journal TEMIDA, Mart 2011, hlm. 8-9.

${ }^{12}$ Hadi Supeno, Kriminalisasi Anak : Tawaran Gagasan Radikal Peradilan Anak Tanpa Pemidanaan, (Jakarta: Kompas Gramedia, 2010), hlm. 196. 
Dari tinjauan pustaka di atas jelas belum menyentuh pada pembahasan tentang dasar/ alasan untuk menentukan kebijakan dalam menggunakan sarana mediasi penal dalam penyelesaian perkara tindak pidana ringan dan urgensi mediasi penal dalam penyelesaian perkara tindak pidana ringan sebagai upaya perwujudan restorative justice. Oleh karena itu, penelitian ini merupakan karya orisinil yang belum pernah ditulis sebelumnya.

\section{Pembahasan}

Dasar/Alasan untuk Menentukan Kebijakan Dalam Menggunakan Sarana Mediasi Penal dalam Penyelesaian Perkara Tindak Pidana Ringan

Proses penyelesaian perkara pidana pada hakikatnya terkait dengan sistem peradilan pidana yang merupakan suatu proses penegakan hukum pidana. Apabila merujuk dari sistem peradilan pidana di Indonesia maka hal ini tidak terlepas dari suatu proses yang berkesinambungan yang meliputi tahap-tahap yang terdiri penyelidikan, penyidikan, penuntutan, persidangan, sampai kepada eksekusi putusan. ${ }^{13}$ Keseluruhan tahapan tersebut dilegitimasi oleh ketentuan perundangundangan yang berkaitan dengan hukum acara pidana, secara umum diatur dalam Kitab Undang-Undang Hukum Acara Pidana (KUHAP) sebagai pedoman sistem peradilan pidana di Indonesia. Di samping itu, ada juga pengecualian-pengecualian hukum acara yang terdapat dalam undang-undang pidana di luar Kitab Undang-Undang Hukum Pidana (KUHP).

Apabila merujuk pada KUHAP yang berlaku saat ini maka tidak ditemukan ketentuan yang mengatur bahwa penyelesaian perkara pidana dapat dilakukan melalui proses mediasi, meskipun perkara tersebut tergolong kejahatan ringan. Semua perkara pidana pada prinsipnya diproses sesuai prosedur yang ditetapkan KUHAP. Namun, untuk penyelesaian perkara dengan menggunakan acara pemeriksaaan cepat, biasanya dilakukan terhadap penyelesaian perkara pelanggaran, seperti perkara tilang lalu lintas dan perkara pelanggaran Peraturan Daerah yang diselesaikan oleh Satuan Polisi Pamong Praja.

Dalam hal penyelesaian perkara tindak pidana biasa seperti penganiayaan hewan ringan (Pasal 302 Ayat (1) KUHP), penghinaan ringan (Pasal $315 \mathrm{KUHP}$ ), penganiayaan ringan (Pasal 352 Ayat (1) KUHP), pencurian ringan (Pasal 364 KUHP), penggelapan ringan (Pasal 373 KUHP), penipuan ringan (Pasal 379 KUHP), perusakan ringan (Pasal 407 Ayat (1) KUHP), penadahan ringan (Pasal $482 \mathrm{KUHP}$ ), yang dikenal oleh sebagian besar masyarakat sebagai kejahatan ringan, masih tetap diproses melalui acara pemeriksaan biasa sesuai prosedur yang berlaku dalam sistem peradilan pidana di Indonesia berdasarkan KUHAP. Untuk perkara tersebut, belum dimungkinkan diselesaikan melalui jalur mediasi penal karena secara normatif, belum ada ketentuan hukum yang melegalkan digunakannya mediasi penal.

Namun, untuk saat ini apabila kejahatan sebagaimana disebutkan di atas masih diselesaikan melalui prosedur acara pemeriksaan biasa tentunya hal ini tidak efektif apabila dibandingkan dengan nilai kerugian yang ditimbulkan oleh pelaku. Apalagi terhadap kejahatan yang tergolong delik aduan dan termasuk juga kejahatan yang dilakukan dalam lingkungan keluarga, patut dipertimbangkan untuk diselesaikan di luar proses peradilan, dalam hal ini dengan mengedepankan mediasi, untuk terwujudnya keadilan bagi kedua belah pihak, yaitu pelaku dan korban.

\footnotetext{
${ }^{13}$ Umi Rozah, Membangun Konstruksi Politik Hukum Mediasi Penal Sebagai Alternatif Penyelesaian Perkara Pidana, Jurnal MHH, Jilid 39, Nomor 3, September 2010, hlm. 284.
} 
Argumen di atas sebagai pertimbangan untuk kebijakan legislatif ke depan dalam rangka pembaharuan KUHAP dengan mengingat bahwa penyelesaian perkara pidana dalam sistem peradilan pidana saat ini apalagi untuk proses pemeriksaan perkara pidana umum melalui pemeriksaan acara biasa melewati prosedur yang cukup panjang mulai dari penyelidikan, penyidikan, penuntutan, sidang pengadilan sampai kepada eksekusi putusan.

Salah satu fungsi hukum sebagai sarana integrasi sosial yang berupa penyelesaian konflik kepentingan dalam hubungan sosial dalam kehidupan masyarakat. Keberadaan hukum sebagai integrasi sosial diwujudkan dengan lembaga pengadilan yang berfungsi mengintegrasikan dan menyelesaikan konflik tersebut, sehingga kehidupan sosial kemasyarakatan kembali nyaman dan tenteram.

Bekerjanya lembaga peradilan dalam proses peradilan pidana berlandaskan pada Undang-Undang Nomor 8 Tahun 1981 tentang KUHAP. Proses peradilan pidana berdasarkan KUHAP sangat berfokus pada pelaku tindak pidana, baik mengenai kedudukannya sejak tersangka sampai menjadi terpidana maupun hak-haknya sebagai tersangka atau pun terdakwa sangat dilindungi oleh KUHAP, sehingga dapat dikatakan bahwa proses peradilan pidana sesuai KUHAP adalah offender minded/ offender oriented criminal justice process. Oleh karena sangat berfokus pada kepentingan pelaku tindak pidana maka kepentingan korban (victim's interests) tidak mendapat tempat di dalam KUHAP.

KUHAP sebenarnya telah mengatur kepentingan korban untuk memperoleh ganti kerugian kepada pelaku melalui keputusan hakim yang berupa pidana bersyarat, mengganti kerugian kepada korban dijadikan sebagai syarat khususnya. Namun demikian, karena hanya sebagai syarat khusus dari pidana bersyarat maka seringkali tidak diterapkan.

Berbicara mengenai sistem peradilan pidana di Indonesia berdasarkan KUHAP, penyelesaian suatu perkara pidana dimulai dari tingkat Kepolisian yang meliputi tahap penyelidikan dan penyidikan, yang dilanjutkan pada tingkat Kejaksaan untuk dilakukan penuntutan ke sidang pengadilan, yang kemudian berujung pada proses di peradilan yang berawal dari sidang di Pengadilan Negeri dan berakhir di Tingkat Kasasi di Mahkamah Agung apabila memang upaya hukum dikehendaki oleh pelaku. Proses yang demikian, cukup memakan waktu yang lama apalagi itu harus dilalui oleh pelaku dalam kasus tindak pidana ringan. Dengan demikian, menurut penulis meskipun belum ada aturan legal yang memberikan payung terhadap keberadaan mediasi dalam perkara pidana, pada tataran implementasi di lapangan penegak hukum dapat mengambil kebijakan yang menguntungkan bagi korban dan pelaku untuk mencapai keadilan restoratif. Namun, untuk tingkat kejaksaan dan pengadilan yang berada di wilayah hukum Kota Pekanbaru tidak menerapkan kebijakan tersebut sebagai bentuk diskresi aparat penegak hukum, kecuali terhadap perkara yang pelakunya adalah anak.

Mediasi penal dapat dilakukan pada semua tingkat proses peradilan pidana. Namun, mediasi seringkali terjadi pada tingkat kepolisian, di mana perkara pidana yang tidak menimbulkan efek besar bagi korban dapat ditawarkan untuk dimediasi, seperti perkara pelanggaran lalu lintas ringan, penyelesaian kasus kekerasan dalam rumah tangga (KDRT) dan terhadap perkara yang pelakunya anak. Namun, untuk saat ini penyelesaian perkara yang mempunyai legalitas untuk diselesaikan melalui proses mediasi hanya terhadap perkara pidana anak, yang dikenal sebagai proses diversi. 
Berkaitan dengan pandangan di atas mengenai alasan penggunaan sarana mediasi penal, ada pendapat lain yang mengatakan bahwa pada dasarnya penggunaan sarana mediasi penal sangat dimungkinkan untuk dijalankan dalam perkembangan hukum ke depan, asalkan ada aturan hukum yang mengakomodir cara penyelesaian perkara dengan sistem tersebut. Namun, sejauh ini penerapan mediasi penal untuk penyelesaian perkara yang berkaitan dengan tindak pidana ringan belum pernah diterapkan di pengadilan pada umumnya, kecuali terhadap penyelesaian perkara yang pelakunya anak dengan menerapkan proses diversi karena memang dimungkinkan oleh undang-undang sistem peradilan anak. Untuk perkara ringan yang nilai kerugian tidak terlalu besar, pengadilan biasanya tetap melanjutkan proses peradilan dengan tetap mempertimbangkan nilai-nilai keadilan dalam putusan terhadap perkara tersebut. Biasanya pertimbangan keadilan restoratif yang dilakukan hakim dalam putusannya dengan memberikan hukuman percobaan kepada terdakwa.

Menurut Lilik Mulyadi, beberapa hal yang menyebabkan suatu perkara diselesaikan melalui proses dua arah sekaligus: ${ }^{14}$

"1. Bahwa mekanisme penyelesaian perkara di luar pengadilan merupakan bentuk penyelesaian dicapai sebagai penyelesaiannya tidak memiliki kekuatan hukum apapun.

2. Ada kekhawatiran bahwa salah satu pihak dikemudian hari terjadi sesuatu hal yang menyebabkan hasil kesepakatan menjadi "mentah" kembali, karenanya masih dimungkinkan untuk diperkarakan kembali dikemudian hari sebelum jatuh tempo daluarsa atas penuntutannya".

Beberapa hal yang patut dipertimbangkan untuk menjadi dasar/alasan untuk menentukan kebijakan menggunakan mediasi penal dalam penyelesaian perkara pidana, dapat dikemukakan sebagai berikut :

Pertama, sebelum membuat kebijakan untuk menggunakan sarana mediasi penal, penegak hukum harus berpedoman kepada asas legalitas bahwa suatu tindakan atau perbuatan harus berlandaskan atas hukum. Dengan demikian, berdasarkan sistem peradilan pidana saat ini yang berdasarkan KUHAP jelas bahwa mediasi penal belum ada dasar hukumnya sehingga tidak dapat diterapkan dalam penyelesaian perkara pidana pada umumnya, khususnya dalam penyelesaian perkara tindak pidana ringan. Untuk melegalkan mediasi penal dalam sistem peradilan pidana perlu dikaji terlebih dahulu konstruksi politik hukum dalam membuat kebijakan untuk memformulasikan konsep mediasi penal yang akan dituangkan dalam aturan normatif yang berlaku umum di masyarakat. Dalam hal ini, pembuat kebijakan legislatif perlu memberikan rumusan yang tegas berkenaan dengan ketentuan mediasi penal. Sehingga untuk ke depan, terhadap perkara tindak pidana ringan atau tindak pidana yang efek atau kerugian ekonomi maupun kerugian sosialnya relatif kecil atau tidak terlalu besar sudah memiliki payung hukum sebagaimana proses diversi yang diterapkan pada sistem peradilan anak.

Kedua, dalam menentukan kebijakan untuk memformulasi mediasi penal dalam sistem peradilan pidana di Indonesia, perlu ditentukan kriteria tindak pidana yang dapat

${ }^{14}$ Lilik Mulyadi, Mediasi Penal Dalam Sistem Peradilan Pidana Indonesia, (Bandung: Alumni, 2015), hlm. 192-193. 
diselesaikan melalui jalur mediasi penal. Adapun kriteria yang dapat dijadikan sebagai pertimbangan, seperti:

1. Tindak pidana yang dapat dimediasikan hendaknya tindak pidana yang hanya diancam dengan ancaman pidana denda atau ancaman pidana penjara paling lama satu (1) tahun.

2. Tingkat kerugian yang ditimbulkan tindak pidana yang dapat dimediasikan haruslah tindak pidana yang menimbulkan kerugian yang kecil saja, seperti dalam pelanggaran dan kejahatan ringan. Contohnya tindak pidana pencurian ringan, penganiayaan ringan, penipuan ringan dan penggelapan ringan.

3. Tindak pidana yang pelakunya anak di bawah umur. Terhadap anak di bawah umur yang melakukan tindak pidana terdapat ketentuan khusus, sehingga proses peradilan pidana yang dijalaninya tidak menimbulkan trauma berkepanjangan yang akan mengganggu perkembangan psikisnya, sehingga dibuka kemungkinan besar untuk penyelesaian dengan jalan proses mediasi penal. Untuk penyelesaian tindak pidana yang dilakukan oleh anak di bawah umur, hal ini sudah diterapkan dalam sistem peradilan pidana anak saat ini, yaitu melalui proses yang dinamakan dengan diversi.

4. Tindak pidana yang merupakan delik aduan baik absolut maupun relatif. Tindak pidana aduan dapat dimediasikan karena penuntutannya didasarkan pada ada atau tidak adanya pengaduan, dan adanya kesempatan bagi korban atau pengadu untuk mencabut pengaduannya sehingga proses tidak sampai berlanjut pada peradilan pidana.

5. Tindak pidana yang melibatkan anggota keluarga sebagai pelaku/korban. Hal ini sejalan dengan salah satu tujuan mediasi penal, yaitu mengintegrasikan dan menyatukan atau memperkuat kembali hubungan antara pelaku tindak pidana dan korban. Dengan demikian, apabila terjadi tindak pidana yang melibatkan anggota keluarga maka dimungkinkan untuk dilakukan proses mediasi penal.

Dengan demikian, khusus untuk perkara tindak pidana ringan maka pertimbangan perlunya penyelesaian perkara melalui mediasi penal karena efek atau kerugian yang ditimbulkan relatif kecil, dari pada harus memberikan pidana perampasan kemerdekaan yang berupa pidana penjara meskipun dengan hukuman percobaan. Seharusnya, penyelesaian diarahkan kepada bagaimana si pelaku bersedia memberikan kompensasi atau ganti kerugian kepada korban, terlebih terhadap perkara yang kerugiannya dapat dinilai secara ekonomi.

Menurut T.J. Gunawan dalam sistem yang menganut paham restorative justice maka untuk memproyeksikan nilai sisem peradilan pidana sebagai sistem yang adil di mata masyarakat, sistem pidana di masa depan harus mengutamakan pengembalian kerugian pada korban yang setimpal yang didapat dari terpidana, kemudian memastikan kepuasan korban terhadap penjatuhan sanksi terhadap tindak kejahatan tersebut, namun harus memiliki batasan maksimum yang pasti. ${ }^{15}$

${ }^{15}$ T.J. Gunawan, Konsep Pemidanaan Berbasis Nilai Kerugian Ekonomi, (Yogyakarta: Genta Press, 2015), hlm. 164. 
Melalui mediasi penal diharapkan proses penanganan perkara dilakukan dengan transparan sehingga dapat mengurangi permainan kotor yang seringkali terjadi dalam proses peradilan pidana tradisional. Mengingat banyaknya keuntungan yang ada pada mediasi penal, sebagaimana telah dipraktikkan dibeberapa negara maka diperlukan upaya berupa kajian untuk menerapkan mediasi penal dalam proses peradilan pidana Indonesia sebagai bagian dari sistem peradilan pidana. Dalam pandangan restorative justice, penggunaan sarana mediasi penal dapat dipandang sebagai suatu proses untuk menuju sistem yang berkeadilan di masyarakat. Sehingga untuk ke depan hasil dari proses sistem peradilan pidana tidak hanya berujung kepada retributif (pembalasan) kepada pelaku, tetapi juga mengutamakan pengembalian kerugian kepada korban baik kerugian yang bersifat material maupun immaterial.

\section{Urgensi Mediasi Penal dalam Penyelesaian Perkara Tindak Pidana Ringan Perspektif Restorative Justice}

Penyelesaian perkara melalui sarana mediasi penal merupakan salah satu proses dari penegakan hukum, sedangkan penegakan hukum itu sendiri merupakan rangkaian proses untuk menjabarkan nilai, ide, cita yang cukup abstrak yang menjadi tujuan hukum. Tujuan hukum atau cita hukum memuat nilai moral, seperti keadilan dan kebenaran. Nilai-nilai tersebut harus mampu diwujudkan dalam realitas nyata. Eksistensi hukum diakui apabila nilai-nilai moral yang terkandung dalam hukum tersebut mampu diimplementasikan atau tidak.

Sehubungan dengan hal tersebut perlu melakukan kajian untuk mencari alternatif lain yang dapat dikembangkan dalam proses penegakan hukum (pidana) terhadap penyelesaian kasus tindak pidana ringan yang lebih berkeadilan. Menurut hemat penulis, penyelesaian kasus tindak pidana ringan yang lebih berkeadilan tersebut sebaiknya diselesaikan melalui sarana mediasi penal karena efek bahaya dan kerugian yang ditimbulkan dari tindak pidana tersebut juga bersifat ringan.

Dalam memandang penyelesaian perkara tindak pidana ringan dari perspektif restorative justice maka penyelesaian melalui sarana mediasi penal dapat dipandang sebagai hal yang penting untuk dilakukan dan perlu mendapatkan payung hukum agar terdapat kepastian hukum dalam pelaksanaannya. Penyelesaian perkara melalui sarana mediasi penal perspektif restorative justice dapat dilakukan dengan mengedepankan musyawarah yang dapat mempertemukan antara pelaku dan korban. Dengan diselesaikannya perkara dengan jalan musyawarah maka hal tersebut dapat diarahkan kepada kesepakatan yang memuaskan kedua belah pihak baik pelaku maupun korban. Dengan demikian, prinsip pemaafan pun akan diketengahkan dalam penyelesaian perkara.

Secara umum, urgensi perlu diterapkannya mediasi penal dalam sistem peradilan pidana di Indonesia, dari aspek administrasi peradilan adalah untuk mengurangi penumpukan perkara. Peningkatan jumlah perkara yang masuk ke pengadilan untuk saat ini menyebabkan semakin banyaknya beban pengadilan untuk menyelesaikan perkara dengan waktu yang terbatas.

Namun, dapat dikemukakan urgensi perlunya mediasi penal dalam penyelesaian perkara tindak pidana ringan apabila dilihat dari perspektif restorative justice, sebagai berikut:

1. Karena masyarakat yang lebih mendominasi berkembangnya sistem hukum

Faktor masyarakat juga mempengaruhi berkembang dan bekerjanya sistem hukum. 
Penegakan hukum berasal dari masyarakat dan mempunyai hubungan timbal balik yang erat. Hubungan sesama manusia dalam masyarakat juga menginginkan bahwa hukum hadir secara berkeadilan. Berbicara mengenai faktor masyarakat berarti membicarakan hukum di ruang sosial. Apabila berbicara mengenai hukum di ruang sosial maka berlakunya hukum di masyarakat dapat pula memperhatikan kearifan lokal yang berlaku, di mana dalam masyarakat Indonesia, budaya damai/ pemaafan sebenarnya sudah banyak diterapkan sepanjang hal tersebut tidak mengandung efek yang sangat membahayakan kepentingan umum.

\section{Perlunya menghadirkan hukum modern menggantikan hukum tradisional}

Hukum sebagaimana diterima dan dijalankan di Indonesia termasuk ke dalam kategori hukum yang modern. Hadirnya hukum modern menjadikan lembaga penegak hukum bukan lagi tempat untuk mencari keadilan (searching of justice), tetapi sebagai lembaga yang berkutat pada aturan main dan prosedur. Keadilan telah mati secara dramatis di lembagalembaga penegak hukum di bawah rezim hukum modern. Selanjutnya, hukum modern tidak saja menyebabkan terjadinya perubahan yang amat besar dan mendasar dalam penyelenggaraan hukum. Kehadiran hukum modern juga tidak jarang menjadi beban bagi masyarakat penerimanya. Hukum modern menjadikan dirinya sesuatu yang esoterik yang tidak bisa begitu saja dimasukkan dan dipahami oleh masyarakat biasa.

Letak tragedi hukum modern, yaitu hukum semakin jauh dari keadilan masyarakat. Penyelesaiannya tidak dapat dilakukan dengan cara berhukum yang biasa dan konvensional. Gagasan progresif inilah yang diharapkan mampu membantu keluar dari kungkungan cara berhukum yang sudah dianggap baku. Kaitannya dengan proses penegakan hukum, sistem peradilan (pidana) formal, yaitu polisi, hakim, jaksa dan kepolisian nyaris kurang memiliki pengetahuan mendalam (bahkan tidak peduli) tentang masalah sosial dari korban seperti latar belakang keluarga dan mata pencaharian. Penegak hukum tersebut hanya melihat tindak kriminalitasnya sehingga saat menangani dan memutuskan perkara, aspek sosial korban cenderung diabaikan. Orientasi kerja pada hasil dari pada proses membuat lembaga peradilan lebih mengejar kuantitas, seperti berapa perkara yang ditangani dan kecepatan menyelesaikan dari pada mempertimbangkan kualitas putusan secara jujur dan adil. Penegakan hukum progesif adalah menjalankan hukum tidak sekedar menurut kata-kata hitam putih dari peraturan (according to the letter), melainkan menurut semangat dan makna lebih dalam (to the very meaning) dari undang-undang atau hukum. Penegakan hukum tidak hanya dengan kecerdasan intelektual melainkan dengan kecerdasan spiritual. Dengan kata lain, penegakan hukum yang dilakukan dengan penuh determinasi, empati, dedikasi, komitmen terhadap penderitaan bangsa dan disertai kebenaran untuk mencari jalan lain dari pada yang biasa dilakukan.

\section{Kesimpulan}

1. Dasar/alasan untuk menentukan kebijakan dalam menggunakan sarana mediasi penal dalam penyelesaian perkara tindak pidana ringan: Pertama, perlu memberikan rumusan yang tegas berkenaan dengan ketentuan mediasi penal. Sehingga untuk ke depan, terhadap perkara tindak pidana ringan atau tindak pidana yang efek atau kerugian ekonomi maupun kerugian sosialnya relatif kecil atau tidak terlalu besar sudah memiliki payung hukum sebagaimana proses diversi yang diterapkan pada sistem peradilan anak. Kedua, dalam menentukan kebijakan untuk mem- 
formulasi mediasi penal dalam sistem peradilan pidana di Indonesia, perlu ditentukan kriteria tindak pidana yang dapat diselesaikan melalui jalur mediasi penal.

2. urgensi mediasi penal dalam penyelesaian perkara tindak pidana ringan perspektif restorative justice dari aspek administrasi peradilan adalah untuk mengurangi penumpukan perkara. Peningkatan jumlah perkara yang masuk ke pengadilan untuk saat ini menyebabkan semakin banyaknya beban pengadilan untuk menyelesaikan perkara dengan waktu yang terbatas. Namun, dapat dikemukakan urgensi perlunya mediasi penal dalam penyelesaian perkara tindak pidana ringan apabila dilihat dari perspektif restorative justice, sebagai berikut: Pertama, karena masyarakat yang lebih mendominasi berkembangnya sistem hukum. Kedua, perlunya menghadirkan hukum modern menggantikan hukum tradisional.

\section{Saran}

1. Landasan yuridis mediasi penal sebagai alternatif penyelesaian perkara pidana saat ini hanya berupa diskresi penegak hukum karena belum diatur pada tataran undang-undang sehingga pada masa mendatang perlu dibentuk suatu peraturan perundang-undangan sebagai payung hukumnya. Payung hukum itu dapat menjadi landasan yuridis yang kuat bagi aparat penegak hukum dalam mewujudkan restorative justice yang tentunya akan lebih memberikan rasa keadilan dan tidak terjadi adanya penyalahgunaan wewenang (abuse of power) dari para pihak yang terlibat dalam sistem peradilan pidana.

2. Praktik mediasi penal yang saat ini telah dilakukan oleh aparat penegak hukum menggambarkan bahwa telah terjadi pergeseran retributive justice menuju restorative justice. Oleh karenanya, diperlukan pengaturan lebih baik dan lebih lanjut mengenai tahap dan proses mediasi penal serta progresivitas setiap aparat penegak hukum dalam rangka penanganan perkara pidana agar keadilan seimbang yang diinginkan dan dibutuhkan oleh masyarakat dapat terwujud.

\section{Referensi}

Apong Herlina. Restorative Justice. Jurnal Kriminologi Indonesia. Volume 3. Nomor III. September 2004.

Arif Nugroho dan Dyah Hapsari Prananingrum. Ketidakadilan dalam Perjanjian Jual Beli Sayur. Jurnal IImu Hukum. Volume 10. Nomor 2. September 2007.

Barda Nawawi Arief. 2008. Mediasi Penal: Penyelesaian Perkara di Luar Pengadilan. Semarang: Penerbit Pustaka Magister.

Hadi Supeno. 2010. Kriminalisasi Anak: Tawaran Gagasan Radikal Peradilan Anak Tanpa Pemidanaan. Jakarta: Kompas Gramedia.

Ivo Aertsen dkk. Restorative Justice and The Active Victim: Exploring the Concept of Empowerment. TEMIDA Journal, Maret 2011, str 5-9, ISSN : 1450-6637 DOI 10.2298/TEM 1101005A Pregledni Rad.

Lilik Mulyadi. 2015. Mediasi Penal Dalam Sistem Peradilan Pidana Indonesia. Bandung: Alumni.

Muladi dan Barda Nawawi Arief. 1998. TeoriTeori dan Kebijakan Pidana. Cetakan II, Bandung: Alumni.

Mushadi. 2007. Mediasi dan Resolusi Konflik di Indonesia. Semarang: Walisongo Mediation Center. 
Muhammad Taufiq. 2014. Keadilan Substansial Memangkas Rantai Birokrasi Hukum. Yogyakarta: Pustaka Pelajar.

S.R. Sianturi dan Mompang Panggabean. 1996. Hukum Penitensia di Indonesia. Bandung: Alumni.

Supriyadi. Mediasi Penal Sebagai Alternatif Penyelesaian Perkara Penggelapan Benda Jaminan Fidusia. Jurnal MMH. Jilid 43. Nomor 3. Juli 2014.

Suratman dan Philips Dillah. 2014. Metode Penelitian Hukum. Cetakan Ke-2. Bandung: Alfabet.
T.J. Gunawan. 2015. Konsep Pemidanaan Berbasis Nilai Kerugian Ekonomi. Yogyakarta: Genta Press.

Umi Rozah. Membangun Konstruksi Politik Hukum Mediasi Penal Sebagai Alternatif Penyelesaian Perkara Pidana. Jurnal MHH. Jilid 39. Nomor 3. September 2010.

Utrecht, E. 1994. Rangkaian Sari Kuliah Hukum Pidana II. Surabaya: Pustaka Tinta Mas.

Wirjono Prodjodikoro. 2003. Asas-asas Hukum Pidana di Indonesia. Jakarta: Refika Aditama. 